\title{
THREE CASES OF THE PERSISTENCE OF THE LEFT SUPERIOR VENA CAVA
}

\author{
ROLLO E. MCCOTTER
}

From the Department of Anatomy, University of Michigan

\author{
THREE FIGUREE
}

Each of the cases of persistent left superior vena cava about to be described is of special interest from the fact that each presents an interesting and somewhat rare condition of the relations of the left superior vena cava to the other venous systems and to the heart. In the first case there is a persistence of the primitive venous system-the cardinal veins-without an apparent attempt at the metamorphosis to the adult condition. In the second case the left superior vena cava not only has the usual origin, course, and termination of this vein but also communicates by a large oval foramen with the left atrium. The left superior vena cava in case three terminates in the left superior pulmonary vein.

Upon reviewing the literature for the reported cases of double superior vena cava the writer has had the opportunity to consult the excellent papers on this subject by Marshall ('50), Gruber ('64), Bauer ('96) and Ancel and Villemin ('08) from whose publications he has freely drawn for certain eited cases, for which the original account was inaccessible.

The above mentioned authors have collected and reported 91 cases of persistent left superior vena cava. To this number the writer will add 29 older and more recent observations. For convenience they have been placed in tabulated form. 
Summary of reported cases of double superior vena cava

\begin{tabular}{|c|c|c|c|c|c|c|}
\hline & ADULTS & $\begin{array}{c}\text { CHILDREN } \\
1-11 \mathrm{YR} .\end{array}$ & NEWBORN & FETTSES & $\begin{array}{l}\text { UNCLASSI- } \\
\text { FIED }\end{array}$ & TOTAL \\
\hline $\begin{array}{c}\text { Double superior vena cava } \\
\text { without anastomosis.... }\end{array}$ & 17 & 5 & 10 & 19 & 13 & \\
\hline $\begin{array}{c}\text { Double superior vena cava } \\
\text { with small anastomosis. }\end{array}$ & 10 & 2 & & 2 & & \\
\hline $\begin{array}{r}\text { Double superior vena cava } \\
\text { with normal anastomosis }\end{array}$ & 9 & & 3 & 4 & 2 & \\
\hline $\begin{array}{c}\text { Left superior vena cava } \\
\text { without right.......... }\end{array}$ & 6 & & 1 & 3 & 2 & \\
\hline $\begin{array}{c}\text { Persistent left superior } \\
\text { vena cava unclassified... }\end{array}$ & 2 & & 2 & 2 & 6 & \\
\hline Total & 44 & 7 & 16 & 30 & 23 & 120 \\
\hline
\end{tabular}

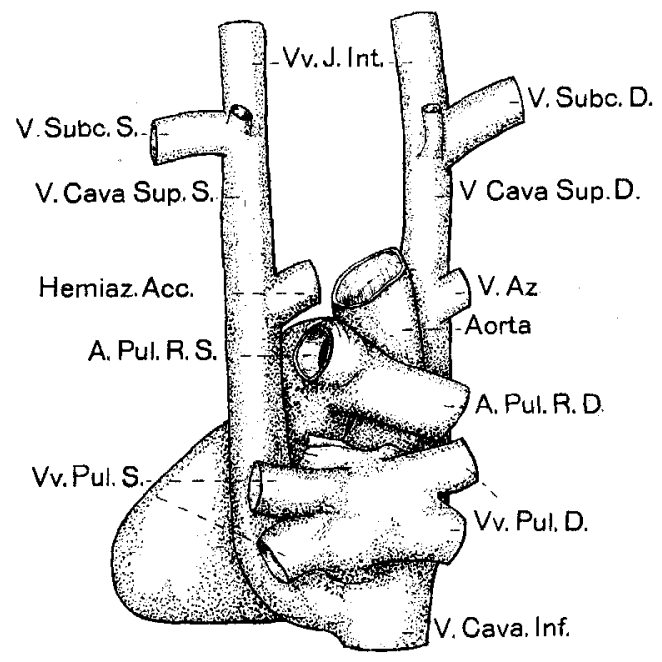

Fig. 1. The dorsal aspect of the heart and great vessels of an adult female showing the origin, course and tributaries of the right and the left superior venae cavae. One-third natural size.

Case 1 was a well nourished female subject of about 35 years of age. The clinical history was not obtainable. The heart shown in figure 1 was of normal size. The grooves on the surfaces were well marked. There were no defects in the interventricular or interatrial septa. The foramen ovale is completely closed. The systemic and pulmonary aortae take origin from the base of the heart and follow the normal course of these vessels. The right superior vena cava 
is formed in the usual way by the union of the internal jugular and subclavian veins. It courses downward in front of the root of the right lung, to the right and posterior to the ascending aorta and terminates in the superior portion of the right atrium. At about $5 \mathrm{~cm}$. below its formation the superior vena cava receives the azygos vein on its posterior wall. The left superior vena cava like the right is formed by the confluence of the internal jugular and subclavian veins and courses downward anterior and to the left of the aortic arch, anterior to the left pulmonary veins, then passes over the surface of the left atrium to enter.the coronary sulcus. It courses to the right around the base of the heart in this groove and terminates in the right atrium anterior and to the left of the opening of the inferior vena cava. At about $5 \mathrm{~cm}$. below its formation it receives the left azygos vein. There is no cross branch uniting the two superior venae eavae, which are of equal size.

By referring to the table it will be seen that there have been 64 cases of this type of duplication of the superior vena cava reported, only 17 of which could be definitely determined as having been observed in adults. Of the remainder 13 could not be classified with regard to the age of the subject.

Case 2 was a well developed male subject about 45 years old. The heart from this subject is very much enlarged. The atria are equal in volume to the ventricles. The left ventricle shares equally with the right in forming the anterior surface. The auricles are much elongated and have fimbriated margins. The aortae have the usual position and relations. The right superior vena cava is formed as usual and takes the ordinary course downward to the right atrium. At about $2.5 \mathrm{~cm}$. below its formation it receives a cross branch (innominate) from the left superior vena cava. $7 \mathrm{~cm}$. below its formation it receives the azygos vein.

The left superior vena cava originates from the union of the left internal jugular and subclavian veins. It passes downward for 2.5 $\mathrm{cm}$. where it sends a branch to the right superior cava. Below this point it becomes reduced to about one-half its former diameter and courses downward anterior to the left pulmonary artery and left superior pulmonary vein and onto the surface of the left atrium. Here it becomes dilated to about four times its former diameter and crosses the surface of the left atrium to reach the atrio-ventricular groove. It courses in this groove to the right around the base of the heart and terminates in the right atrium anterior and to the left of the termination of the inferior vena cava. At the level of the inferior pulmonary vein in its course over the surface of the left atrium in the terminal dilated portion of the left superior vena cava is a large oval foramen, $3.5 \mathrm{~cm}$. in a vertical diameter and $1.5 \mathrm{~cm}$. in a horizontal diameter, which communicates with the left atrium. 
Although the duplication of the superior vena cava has been observed to be relatively frequent in man the writer has been unable to find a reported case where the left superior vena cava communicated with the left atrium. However, of interest in this connection is the case of Ring (1805), in which the left superior vena cava terminated in the left atrium together with the inferior vena cava. Büttner-Weese (1769-1819) described one case and Breschet ('26) two cases where the left superior vena

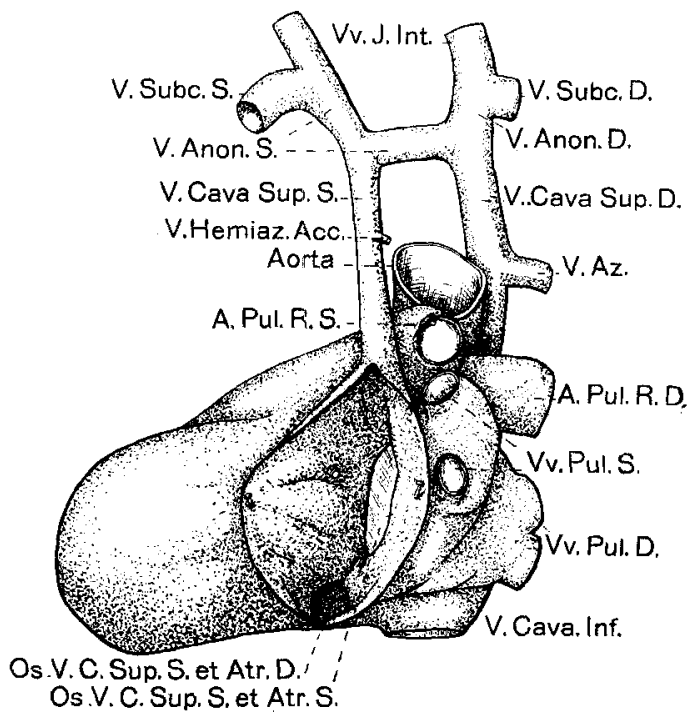

Fig. 2. The heart and great vessels of an adult male viewed from the left and dorsally. It shows the origin and course of the left superior vena cava and its communication with the right and the left atrium. One-third natural size

cava terminated in the left portion of a common atrium in the newborn. Martin ('26) states that he saw, in a 1.5 months old child, the left superior cava ending in the left atrium. There were also many other disturbances of development. In Gruber's ('46) case the left superior vena cava terminated in the highest portion of the left atrium. Luschka ('62) described the left superior vena cava in a newborn child that terminated in the left atrium just anterior to entrance of the left pulmonary veins. It will be seen that the reported cases of left superior vena cava 
have been observed only in very young infants and in the majority of them this anomaly was accompanied by other disturbances of development. It is questionable if Gruber's case should be included in this group because this anomaly might be produced by a union between the left superior pulmonary vein and the left superior vena cava, the union between the former and the lung having been lost early.

In this catagory may be included, also, those cases where the coronary sinus communicated with the left atrium but where the left primitive anterior veins have passed through the usual metamorphosis to the adult human condition. Four of these cases have been reported. Lindner (1787) observed an instance where the coronary sinus terminated in the left atrium. Jeffray describes the same condition in the heart of a fetus. Meckel (1816) reports a similar condition in his text-book. A case was seen by Bauer ('96) in which he describes very carefully a coronary sinus that communicated with the left atrium by an oval foramen $14 \mathrm{~mm}$. and $11 \mathrm{~mm}$. in transverse and antero-posterior diameter respectively. The usual communication between the coronary sinus and right atrium was completely closed.

Case 3 is a well developed male subject 57 years of age. The heart as shown in figure 3 is apparently normal. The aortae and the right superior vena cava have their usual relations. The left superior vena cava is formed by a very large subclavian vein uniting with a small internal jugular. It courses obliquely downward and to the right for $3 \mathrm{~cm}$. where a large branch passes across the mid-line to the right superior cava. Below the point where the branch is given off to the right side the left superior vena cava is about one-third its original diameter. After coursing downwards for $4 \mathrm{~cm}$. it terminates in the left superior pulmonary vein. The pulmonary vein, which appears to be situated higher in the hilum than usual, is formed by the confluence of three veins from the upper lobe of the left lung. After coursing downward and to the right it terminates in the upper part of the posterior wall of the left atrium. The left inferior pulmonary vein has the usual course and termination.

The somewhat rare condition of a communication between the left pulmonary veins and the persistent left superior vena cava or with a persisting portion of this channel has been reported eleven times. These cases may be separated into four groups 
according to the portion of the anterior cardinal vein that remains patent and offers a drainage channel for a portion of the left lung either into the right atrium by way of the innominate vein or the coronary sinus or as a channel by which a large part of the venous blood from the upper part of the left side of the body reaches the left atrium.

In those cases where the left superior vena cava has the usual origin, course and termination, Wilson (1798) was the first to report a case where left pulmonary veins terminated in the

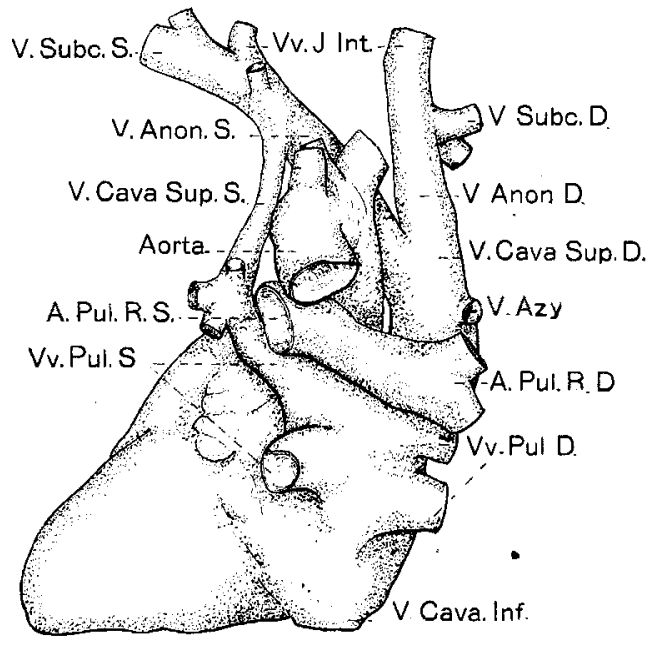

Fig. 3. The heart and great vessels of an adult male viewed from the left and dorsally. It shows the origin and course of the left superior vena cava and its termination in the left superior pulmonary vein. One-third natural size.

left superior vena cava. His case was a malformed child. Theremin ('95) described a similar condition in a child two months old. In the second class of cases the left superior vena cava has the usual origin of this vein; it courses downward and terminates in the pulmonary vein which terminates as usual. In these cases there is a well formed coronary sinus. Case 3 as described in this communication is of this type. Hyrtl ('39) observed 2 cases, one in a newborn female child the other in a 60 -year-old male, where the left superior vena cana joined the left superior pulmonary vein which terminated as usual in the 
left atrium. Somewhat more recently Revilliod ('89) described a condition where the upper persisting portion of the anterior cardinal veins entered the left atrium together with the left pulmonary veins. This anomaly occurred in a 3 months old female child.

The third group of cases presents the proximal portion of the anterior cardinal veins alone persisting and gives the appearance of the coronary sinus originating in the pulmonary veins. The pulmonary veins have lost the usual connection with the left atrium. Hickman ('69) states that in a female 28 years of age the pulmonary veins from the left lung enter the right atrium. This interesting condition is produced by the union of the pulmonary veins with the coronary sinus through a persistent portion of the duct of Cuvier. Somewhat more clearly Nabarro ('03) describes this condition in a $5 \frac{1}{2}$ months old child. In this case all of the pulmonary veins opened into the right atrium by way of a large coronary sinus.

Finally, in the fourth group the persistent portion of the left anterior cardinal has lost its connection with the left duct of Cuvier (coronary sinus) which gives the appearance of the pulmonary veins terminating in the left innominate vein. The pulmonary veins in these cases have lost the connection with the left atrium. Blair ('02) claims that a pulmonary vein, normal in size, originating in the superior lobe of the left lung terminates in the left innominate vein. Somewhat similar was the case of Thane ('06) where a superior pulmonary vein entered the left innominate in an adult. Patterson ('13) discovered a case where the upper lobe and the superior half of the inferior lobe drained into the left innominate vein. Nützel ('14) states that Ramsbotham observed a case where the left superior pulmonary vein terminated in the left subclavian vein. Johnston ('15) very clearly describes a case where the left superior pulmonary vein joins the upper persisting portion of the left superior vena cava, the left superior vena cava terminated in the left innominate vein and the coronary sinus was completely formed.

Under this general grouping may also be included those cases reported where there is a communication between the right 
superior pulmonary veins and the normal superior vena cava. The causative factors are the same in either case. Meckel ('20) observed the right superior pulmonary vein terminating in the superior cava in an adult. In his short notes Otto ('30) shows the pulmonary vein ending in the right atrium. Cooper ('36) and Chassinat ('36) each describe a case where the right pulmonary vein ended in the superior cava. Somewhat more clearly Lambl ('60) describes this abnormality. He reports the communication of the right pulmonary vein with the right atrium. Törster ('61) presents in his work on the anomalies of the human body a note on the origin or the termination of the pulmonary veins in the superior or the inferior vena cava without giving the details in these cases. Somewhat indefinitely Duchek ('62) states that he observed the left superior vena cava arising in the right superior pulmonary vein, in a male adult. Gruber ('76) states that he saw the right superior pulmonary vein communicating with the superior vena cava. Gegenbauer ('60) describes a case in a 2 year old child where the right superior pulmonary vein ends in the superior vena cava. Chiari ('80) observed the abnormal termination of the right pulmonary vein in the right atrium. Gruber ('80) described a case where the right pulmonary vein terminated in the superior vena cava in an adult female. Töpley ('82) observed this interesting abnormality: in a 20-year old male subject the superior vena cava is formed as usual; shortly after receiving the azygos vein it divides into two limbs, the ventral terminating as the ordinary vena cava superior and the posterior limb, after passing between the branches of the right pulmonary artery and bronchus, enters the left atrium. In a case having anomalies of many organs Epstein ('86) described the right and left pulmonary veins uniting to form a common trunk which courses behind the heart and terminates in the superior vena cava. Rokitansky ('86) mentions in his text-book on pathological anatomy a case of abnormal termination of the right pulmonary vein in the right superior cava. He also describes a case where the right pulmonary veins terminated in the right atrium. In his description of a double superior vena cava Hepburn ('87) has shown 
that the right pulmonary vein opened into the right atrium. Miura ('89) describes the finding at autopsy on a 6 months old child the two right and the two left pulmonary veins united into a small vein on each side and these finally uniting to form a single trunk before terminating in the azygos vein. The azygos vein communicates with the upper part of the right atrium. Shepherd ('90) observed a case where the single right pulmonary vein terminated in the azygos vein just before it arched over the root of the lung. Audry and Lacroix ('90) mention a case where the right pulmonary veins joined the right atrial wall. Etlinger ('91) briefly states that he observed a similar case where the right pulmonary vein entered the right atrium. Ingalls ('07) states that two right pulmonary veins communicated with the superior cava just before it terminated in the right atrium in his case. A third pulmonary vein terminated as usual. Stoeber ('08) reported a case of 'cor triatriatum' where the pulmonary veins from the right and left lower lobes of the lungs terminated in the left atrium. The pulmonary veins from the upper lobes terminated in the right atrium. Schröeder ('11) described a case which he observed in a 26-day old child where the left superior vena cava terminates in the left atrium and the right pulmonary veins communicate with the right innominate vein. Merkel ('12) has observed a case in a 70-year old male subject in which the right pulmonary vein communicated with the superior vena cava and also with the left atrium. Brown ('13) in describing Doctor Park's case states that the right pulmonary veins joined the superior cava. There were no right pulmonary veins that entered the left atrium. Gerard ('14) interestingly describes a case where the right superior pulmonary vein entered the superior cava. Nützel ('14) also describes a similar condition observed in a 47-year old subject.

The embryological significance of the persistence of the left superior vena cava as shown in figure 1 has been so frequently described that a detailed discussion of this unusual condition is deemed unnecessary at this time. Case 2, however, in which in addition to the complete persistence of the left anterior car- 
dinal vein and duct of Cuvier there is a communication between this venous channel and the left atrium deserves further consideration. In the text-book of human embryology edited by Keibel and Mall it is stated that there develops in the early fetal heart, beside the atrial and ventricular chambers, a third chamber, known as the sinus venosus. The sinus venosus becomes elongated laterally into the right and left sinus horns. The sinus communicates with the common atrial chamber by a large oval foramen with its long axis placed transversely. During the normal course of development the left sinus horn becomes reduced in size, and finally loses its connection with the left cardinal vein. At about the same time the left half of the large oval foramen connecting these two chambers becomes constricted so that the opening becomes reduced to less than half its original diameter. The interatrial septum develops just to the left of this constricted opening. It appears quite probable that in Case 2 the left sinus horn and the oval foramen uniting the sinus venosus and the common atrial chamber did not undergo the usual changes as very briefly described above but developed proportionately with these structures on the right side. With the development of the interatrial septum, dividing the common atrium into right and left portions, the large oval foramen uniting the sinus venosus and common atrium, and which remained undiminished in size, also became divided into right and left portions and maintained a communication with the right and left atrial chambers respectively.

In his description of the development of the pulmonary veins for the cat Brown ('13) has shown in $4.5 \mathrm{~mm}$. embryos and in his figure 1 that the anlage of the pulmonary veins and the anterior cardinal veins are connected with an indifferent capillary plexus surrounding the foregut and lung anlage. Undoubtedly, then, the communication of the pulmonary veins with the left superior vena cava as is shown in figure 3 is the persistence of the primary condition described above. In the writer's case that portion of the left anterior cardinal vein between the level of the superior pulmonary vein and the heart has undergone the usual changes that are found in man. The 
left superior vena cava in this case gives the appearance of terminating directly in the superior pulmonary vein.

In conclusion I beg to thank Mr. Atwell for the execution of the drawings which were prepared according to the methods he described in volume 10 of the Anatomical Record.

\section{LITERATURE CITED}

Audry, C. et Lacrorx, E. 1890 Lyon Méd.

AnCel, P. ET Villemin, F. 1908 Sur la persistance de la veine cave superieure gauche chez l'homme. Jour. de l'anat., vol. 44, pp. 46-62.

BAUER, K. 1896 Ein Fall von Verdoppelung der oberen Hohlvene und ein Fall von Einmündung des Sinus coronarius in den linken Vorhof. Morph. Arbeiten, vol. 6, pp. $221-242$.

Beyerlein, K. 1914 Die persistierende Vena cava superior sinistra als Abflussrohr für das Coronarvenenblut. Frankfurter Zeit. f. Path, vol. 15, pp. 327-332.

Birmingham, A. 1893 Extreme anomaly of the heart and great vessels. Jour. Anat. Physiol., vol. 27, pp. 139-150.

BlaIr, V. P. 1901 Three anomalies of the thoracic blood vessels. Am. Jour. Anat., vol. 1, p. 513 .

Breschet, G. 1826 Mém. sur l'ectopie de l'appariel de la circulation et particuliórment sur celle du coeur. Répert. génér. d'anat. et Physiol. Path. et Clinique Chirurg., vol. 2, p. 1 .

Brown, A. J. 1913 Development of the pulmonary veins in the domestic cat. Anat. Rec., vol. 7, pp. 299-315.

Büttwer-Weese, 1769-1819 Anat. Wahrnehmungen. Königsberg u. Leipsig, No. 5, p. 36 .

Cameron, J. 1915 A specimen showing complete remains of the left superior vena cava with a description of a venule which represents the 'lost' intrapericardial portion of the duct of Cuvier. Jour. Anat. Physiol., vol. 49 , pp. 140-147.

Chassinat. 1836 Archiv. Generales de Médicine. Jour. complem. Des science Med., Paris., Ser. II, vol. 41, p. 80.

Chinar, H. 1880 Aus der Prosectur des St. Anna-Kinderspital in Wien. Jahrb. f. Kinderheilkunde, Bd. 15, S. 319-323.

Cooper. 1836 London Med. Gazette, vol. 18, p. 600.

Dietrich, A. 1913 Über ein Fibroanthrosarkom mit eigenartiger Ausbreitung und über eine Vena cava superior sinistra bei dem gleiden Fall. Archiv f. Path. Anat., Bd. 212, S. 119-139.

Duchex. Die Krankheiten des Herzens. Erlangen 1862, S. 67.

Epstern, A. 1886 Beitrag zu den Bildungsfehlern des Herzens. Zeitschr. f. Heilkunde, Bd. 7, S. 308-322.

Etunger, N. 1891 Zur Causistik der angeborenen Herzfehler. Archiv f. Kinderheilkunde, Bd. 12, S. 348-359. 
Frtzgerald, D. P. 1909 The study of developmental abnormalities, etc. Dublin Jour. Med. Sci., vol. 127, p. 14.

Gérard, G. 1914 Anomalie vasculaire rare. Soc. de Biol., vol. 77, pp. 131-133.

Golubew, W. W. 1895 Ein Fall von Vena cava superior duplex. Whatsch., No. 37 .

Gruber, W. 1846 Anatomisehe Mittheilungen. Vierteljahr. f. prakts. Heilkunde., Bd. 9, S. 78 .

1864 Duplicität der Vena cava superior. Mém. de l’Acad. Imp. des sc. de St. Petersbourg, Ser. 7. Tom. 7, No, 2, S. 45.

1876 Ein Fall von Einmündung der Vena pulmonalis dextra superior in die Vena oava superior. Archiv f. Path. Anat., Bd. 68, S. 284-287. 1880 a Duplicität der Vena cava superior, mit Vorkommen zwier Venae azygae und einer sufficienten Valvula an der Mündung der Vena azygos sinistra. Archiv f. path. Anat., Bd. 81, S. 462-465.

$1880 \mathrm{~b}$ Vorkommen einer Vena cava superior sinistra. Archiv f. path. Anat., Bd. 81, S. 458 .

Gegenbauer, C. 1880 Ein Fall von Einmündung der oberen rechten Lungenvene in die obere Hohlvene. Morph. Jahrb., Bd. 6, S. 315.

HePBURN, D. 1887 Double superior vena cava, right pulmonary veins opening into the right auricle and a special interauricular foramen. Jour. Anat and Physiol., vol. 21, pp. 438-443.

Hickman, W. 1869 Transposition of viscera; malformation of heart, pulmonary veins from the right lung entering the left auricle, and from the left lung entering right auricle. Tr. Path. Soc., vol. 20, p. 93.

Hutton, W. K. 1915 An anomalous coronary sinus. Jour. Anat. and Physiol., vol. 49 , pp. 407-413.

Hyrtц, J. 1839 Venen varietaten. Med. Jahrb. d. K. K. osterreichen Staates, Bd. 18.

INGALIS, N.W. 1907 Communication between the right pulmonary veins and the superior vena cava. Anat. Rec., vol. 1, p. 14.

JEFFRAY, J. 1835 Observations on the heart of a fetus. Quoted by Marshall.

Johnsron, T. B. 1860 A rare vascular anomaly; opening of the upper left pulmonary vein into a persistant left superior vena cava. Jour. Anat. Physiol., vol. 49, pp. 182-186.

Lambl, D. 1860 Aus dem Franz Joseph Kinderspital in Prag., I Teil, S. 132.

LeBlanc, R. 1915 A left superior vena cava. Guy's Hospital Gaz., vol. ¿9, p. 52.

LECAt, C. 1738 Hist. de l'Acad. roy. des se. Paris $1740,4^{\circ}$, p. 44.

Loschка, H. 1862 Anat. des Mensch., Bd. 1, 2 Abth., S., 439.

Martin, G. 1826 Bull. de la soc. Anat. de Paris., 2 edit. Paris 1841, pp. 39-43

Mecker J. F, 1816 Handb. der Mensch. Anat., Bd. 3, S. 67.

1818 Úber einige seltene Bildungsabweichungen. Deutsch. Archiv f. d. Physiol., Bd. 4, S. 479-480.

1820 Einmündung der Vena pulmonalis dextra superior in die Vena cava superior. Tab. Anat. Path., Fase. 2, Leipsig.

Merkel, H. E. 1912 a Missbildung im Bercich der oberen Hohlvene. Muenchener medizinische Wochenschrift., Bd. 59, S. 615.

1912 b Missbildung der oberen Hohlvene. Muenchener Medizinische Wochenschrift., Bd. 59, S. 110 . 
Midra, M. 1889 Ein Fall mit angebornen Herzanomalien. Archiv f, path. Anat., Bd. 115, S. 353 .

Nabarro, D. 1903 Two hearts showing peculiarities of the great veins. Jour. Anat. Physiol., vol. 37, pp. 382-391.

Neuberger, H. 1913 Ein Fall von vollkommener Persistenz der linken Vena cardinalis posterior bei felender Vena cava superior. Anat. Anz., Bd. 43 , S. $65-80$.

NÜrzel, H. 1914 Beitrag zur Kenntnis der Missbildungen im Bereiche der oberen Hohlvene. Zeitschr. f. Path., Bd. 15, S. 1-19.

OTro, A. 1830 Lehrbuch der path. Anatomie.

Patterson, J. 1913 An unusual anomaly of the left pulmonary vein. Jour. Amer. Med. Assn., vol. 61, p. 1898.

Reviluion, E. 1889 Anomalie du coeur... Anomalies arterielles et veineuses. Revue médic. de la Suirre Romande Genéva, no. 3, p. 159.

RiNG, R. 1805 Med. and Phys. Jour., London, vol. 13, p. 120.

Robertson, J. I. 1914 Cardiac malformations in which the great efferent vessels arise from the right ventricle. Heart, London, vol. 6, pp. 99-104.

Rochevalier, M. 1909 Sur la persistance de la veine cave supérieure gauche chez l'homme. Thése., Montpellier. Quoted in Jahresberichte der Anat. u. Entwicklung., Bd. 15, Abt. 3.

Rockitansky, C. 1886 Lehrbuch der path. Anat., Bd. 2, S. 248.

SCHRÖEDER, R. 1911 Úber anomalien der pulmonalvene zugleich im beitrag zum Cor biloculare. Archiv f. path. Anat., Bd. 205, S 122.

SHEPFERD, F. J. 1890 Right pulmonary vein emptying into vena azygos major. Jour. Anat. Phsyiol, , vol. 24, pp. 69-70.

Stokber, H. 1908 Ein weiterer Fall von Cor triatriatum mit eigenartig gekreuzter Mündung der Lungen-venen. Archiv f. path. Anat,, Bd. 193, S. 252.

Thane, G. D. 1906 A specimen in which the upper pulmonary vein of the left side opens into the innominate vein. Jour. Anat. Physiol., vol. 40, p. xi.

Theremin, E. 1895 Etudes sur les affections congenitales du coeur. Paris.

Trchomiroff, M. 1895 Ein Fall von conginitalen Mangel der linken Lunge mit Persistenz der linken oberen Hohlvene bei einem erwachsenen. Mensch. Internat. Monatssch. f. Anat., Bd. 12, S. 37.

Töpley, R. 1882 Eine neue varietät der oberen Hohlvene. Prag. Mediz. Wochenschr., Bd. 7, S. 223-234.

Törster. 1861 Missbildungs des Mensch. Jena., S. 145.

Walsham, W. J. 1880 Anatomical variations. Bartholom. Hosp. Reports, vol. 16, p. 93 .

Wilson, J. 1798 On a very unusual formation of the human heart. Philos. Trans. Abridg., London, pt. 1, pp. 332-333 